\title{
Electricity Market Mechanism regarding the Operational Flexibility of Power Plants
}

\author{
Cem Kiyak, Andreas de Vries \\ Department of Technical Business Administration, South Westphalia University of Applied Science, Hagen, Germany \\ Email: de-vries.andreas@fh-swf.de
}

How to cite this paper: Kiyak, C. and de Vries, A. (2017) Electricity Market Mechanism regarding the Operational Flexibility of Power Plants. Modern Economy, 8, 567589. https://doi.org/10.4236/me.2017.84043

Received: March 10, 2017

Accepted: April 24, 2017

Published: April 27, 2017

Copyright $\odot 2017$ by authors and Scientific Research Publishing Inc. This work is licensed under the Creative Commons Attribution International License (CC BY 4.0).

http://creativecommons.org/licenses/by/4.0/

\section{(c) (i) Open Access}

\begin{abstract}
Electricity market mechanisms designed to steer sustainable generation of electricity play an important role for the energy transition intended to mitigate climate change. One of the major problems is to complement volatile renewable energy sources by operationally flexible capacity reserves. In this paper, a proposal is given to determine prices on electricity markets taking into account the operational flexibility of power plants, such that the costs of longterm capacity reserves can be paid by short-term electricity spot markets. For this purpose, a measure of operational flexibility is introduced enabling to compute an inflexibility fee charging each individual power plant on a wholesale electricity spot market. The total sum of inflexibility fees is accumulated on the spot markets and then can be used to finance a capacity mechanism keeping the necessary reserves to warrant grid reliability. Here each reserve power plant then gets a reliable payment depending on its operational flexibility. The proposal is applied to an exemplary small grid, illustrating its main idea and also revealing the caveat that too high fees paradoxically could create incentives to employ highly flexible power plants on the spot market rather than to run them as backup capacity.
\end{abstract}

\section{Keywords}

Electricity Market, Market Mechanism, Renewable Energy, Operational Flexibility of Power Plants, Energy Transition

\section{Introduction}

To mitigate the global climate change, it is commonly agreed that greenhouse gas emissions, and in particular emissions of $\mathrm{CO}_{2}$, have to be reduced substantially [1]-[6]. Since $85 \%$ of current primary energy driving global economies are due to the combustion of fossil fuels, and since consumption of fossil fuels accounts for $56.6 \%$ of all anthropogenic greenhouse gas emissions, introducing 
renewable energy sources to support all areas of human life plays an essential role in fighting global warming [7]. In particular, the generation of electricity by renewables will be an important step towards this goal, requiring substantial changes to current grid structures and power plant systems.

If generation and distribution of electricity is to be organized by market principles, a preeminent challenge of a future electricity market mechanism design is to set effective price signals to reward the introduction and the use of renewable energy sources for the generation of electricity, and simultaneously to penalize fossil fuel power plants. However, the physical requirements of electricity grids and the necessities of public life in present societies impose special restrictions on electricity markets. In particular, a necessary condition for grid stability is the reliability of electricity generation and the immediate equality of supply and demand at any instant of time. It is expected that the biggest contribution of renewable energy sources in electricity grids will come from wind turbines and photovoltaic cells [8], both producing electricity only with high volatility. Their widespread installation therefore would challenge the reliability of electricity supply and thus the stability of the grids. Lacking sufficiently large storages for electricity, to warrant reliability in grids with volatile energy sources power plants with high operational flexibility are required as a power reserve standing in in cases of sudden scarcity of electricity supply or of blackouts.

Cramton and Ockenfels [9] proved the "missing money" theorem stating that, in a competitive electricity market, prices are always too low to pay for adequate capacity. In fact, present electricity markets are not perfectly efficient markets since both supply and demand are price inelastic, see Figure 1 and Theorem 1 below. Future increase of demand elasticity, for instance by smart grids, would relax the difficulties to a certain degree, but inelasticity on the supply-side could only be removed by capacity reserves or huge electricity storages. The first option, however, requires long-term plannings at a magnitude of decades, whereas
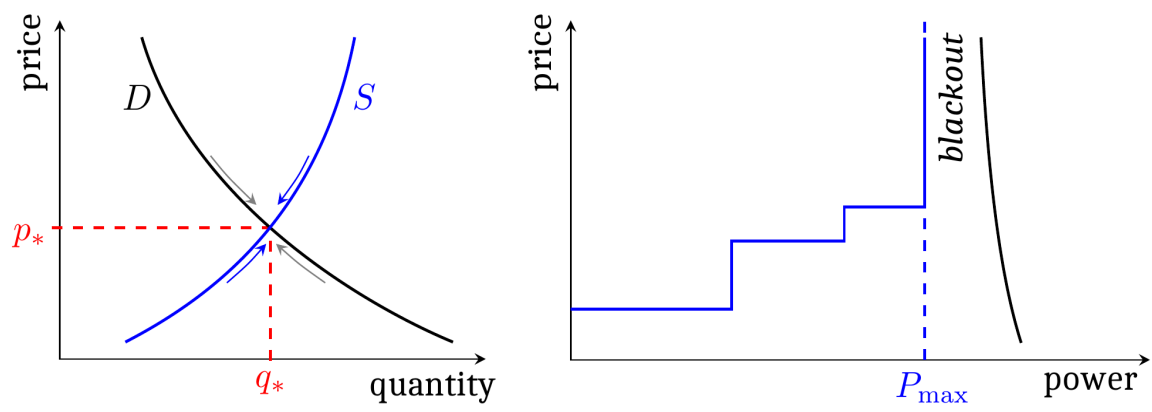

Figure 1. A perfect efficient market where any demand $D$ meets supply $S$ at a certain equilibrium price $p$ and quantity $q$ (left hand). On an electricity spot market, a blackout is a market failure due to inelastic demand and supply, with the supply curve given by the merit order of the power plant system (right hand). Here a ("rolling") blackout occurs if the demand is higher than the total maximum power $P_{\max }$ of all power plants [10]. Increasing the demand-side inelasticity, e.g., by smart grids, could remove the problem on the long run, but in the short run electricity markets require capacity reserves which are not demanded for most of the time. Rolling blackout as a market failure due to inelastic demand and supply. 
the second option is technologically not realizable to date. For more details see [10].

Besides these theoretical arguments there also exist empirical clues to doubt that current electricity markets encourage investments in operationally flexible power plants or in the provision of power reserves for cases of emergency or maintenance [11] [12] [13] [14]. Several solutions to this problem have been proposed recently to complement the present "energy-only" markets, ranging from separate capacity markets which trade backup capacity, to strategic capacity reserves usually settled by long-term contracts with national agencies [9] [11] [13] [14] [15] [16] [17].

The main goal of this paper is to propose a solution to the economic problem of financing the necessary capacity reserves guaranteeing grid stability by market principles. One necessary property of a power plant for being part of a capacity reserve is a fast guaranteed operational flexibility. In our opinion the main problem of current market mechanism designs is the fact that market prices do not regard operational flexibility, being determined solely by the marginal costs of electricity generation. Thus the costs of operational inflexibility are market externalities [18] [19] and reduce welfare.

By contrast, a sustainable electricity market mechanism design should induce market prices which take into account both the direct variable production costs and the external ecological costs of electricity production, but also the costs caused by operational inflexibility of each individual power plant. Due to emissions trading [20], the first two cost factors are already priced in as marginal costs on present electricity spot markets, at least in principle [21], but operational flexibility does not play a role for the determination of the spot market prices to date. To internalize it into price calculation, at first we define a measure for the operational flexibility of a given power plant. This measure then can be used to compute an inflexibility fee for each power plant. The total of these inflexibility fees then can serve to pay power reserves provided by some given capacity mechanism.

The paper is organized as follows. We first summarize the specialties of electricity markets and its market deficiencies when a pure market mechanism is established. After some capacity mechanisms are listed which ensure grid reliability, we present a new market mechanism giving rational incentives to maintain capacity reserves. A short discussion concludes the paper.

\section{Electricity Markets}

An electricity market is a mechanism by which suppliers and demanders of electricity interact to determine price and quantity of electrical energy or electrical power. Due both to the physical requirements and the historical evolution, an electricity market consists of four types of participants, forming the four stages generation, transmission, distribution, and consumption (Figure 2): the power plant operators generating electricity, the transmission system operators (TSO) transmitting electrical power to regional electricity distribution operators, the 


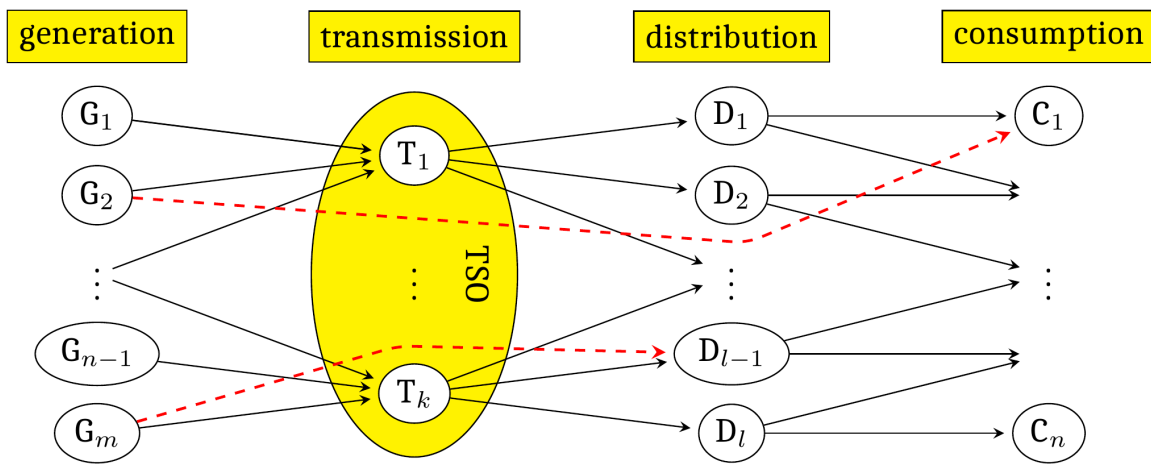

Figure 2. General structure of an electricity market, largely determinded by the four stages. The dashed lines indicate individual OTC forward contracts of power plant companies $G_{i}$ and utilities $D_{j}$ or consumers $C_{j}$

utilities and finally the consumers, usually households, firms, or transport companies.

In most electricity markets, the power plant operators sell electric energy to big consumers or utilities via contracts, usually OTC forwards, or via a spot market to utilities. The utilities, in turn, sell the electricity to the consumers. The task of the transmission system operator is to coordinate the dispatch of generating units to meet the expected demand of the system across the transmission grid and to warrant the stability of the system. Such electricity markets therefore are partitioned into wholesale markets where the power plant operators offer electricity to retailers, and a retail market where the retailers themselves re-price electricity and sell it on the market to consumer, or use it in case of big industry companies.

Trading electricity has several specialties in comparison to trade other goods, resulting from its physical properties [20]. One important property is that electricity cannot be stored to a relevant degree. This implies that the trade of electricity is strongly and directly dependent from the momentary production conditions and therefore cannot be buffered in periods of low demand for later times of peaks of demand. Each generator being limited in its supply capacity, the market capacity is constrained, and the total demand $q$ is fixed at each moment of time. Moreover, electricity is a perfectly homogeneous good, that is, there is no product differentiation and demanders are indifferent to generators. As a result, the generation of electricity can be considered as a Cournot oligopoly of $N>1$ power station operators as economic agents, where generators are able to choose their level of supply but not the price which they receive for the electricity that they generate. In general, a Cournot oligopoly with $N$ agents is described by the following notions:

- The number $N>1$ of agents is fixed, known to all agents, and all agents produce the same homogeneous good;

- the agents do not cooperate, i.e., there is no collusion, and have market power, i.e., each agent's output decision affects the good's price;

- agents compete in quantities and choose them simultaneously; in particular, firm $i$ chooses quantity $q_{i}$ 
- the market-clearing price $p$ of the good is a commonly known decreasing function $p(q)$ of the total output quantity $q=q_{1}+\cdots+q_{N}$.

- the agents are economically rational and act strategically, seeking to maximize profit; agent $i$ has a marginal cost function $c_{i}\left(q_{i}\right)$ increasing on its chosen quantity $q_{i}$ and agent $i$ s total profit is

$$
u_{i}\left(q_{1}, \cdots, q_{N}\right)=q p(q)-c_{i}\left(q_{i}\right) .
$$

For more details see [22] [23]. The price of electricity is therefore determined by market demand and may be assumed, at least approximately, to be linear, $p=$ $a-b q$, with positive constants $a, b>0$. If we moreover assume the cost function of agent $i$ as given by $c_{i}\left(q_{i}\right)=c q_{i}+d q^{2}$ with positive constants $c, d>0$, and $a>$ $c$, then the Nash equilibrium of this Cournot system is given by

$$
q_{i}^{*}=\frac{a-c}{b(N+1)}, \quad p=\frac{a-N c}{N+1}, u_{i}=\frac{(a-c)^{2}}{b(N+1)^{2}} \text {. }
$$

Furthermore, since demand and supply vary continuously, there is a physical requirement for a controlling agency, the transmission system operator, to coordinate the dispatch of generating units to meet the expected demand of the system across the transmission grid. There are some commonly accepted and empirically founded design structures for electricity markets, namely to separate the potentially competitive functions of generation and retail from the natural monopoly functions of transmission and distribution; and to establish a wholesale electricity market and a retail electricity market (Figure 3 ).

The role of the wholesale market is to allow trading between generators, retailers and other electricity markets have been implemented in regions all over the world, some of them listed in Table 1 . The concepts of electricity markets emerged from trends towards liberalization starting in the 1990's. Due to dys-

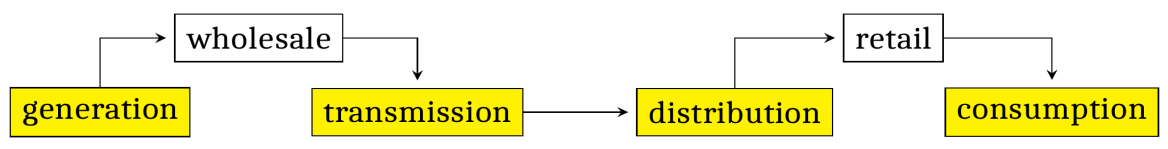

Figure 3. Electricity markets and physical stages.

Table 1. Electricity markets and their designs. Data from [20].

\begin{tabular}{ccc}
\hline Electricity Market & Region & Model \\
\hline APX & Netherlands & open \\
EEX & Central Europe & open \\
GME & Italy & open \\
Powernet & France & open \\
CCE & Brazil & pool-based \\
NEMMCO & Australia & pool-based \\
NordPool & Scandinavia & pool-based \\
Omel & Spain & pool-based \\
PJM & USA & pool-based \\
\hline
\end{tabular}


functional experiences, especially the Californian electricity crisis in 2000/2001 and the New York blackout in 2003 damped the initial political enthusiasm for reform [24]. Apart from a small number of electricity market reforms in Australia, New Zealand, Chile and Argentina, mainly the European Union pursued a comprehensive energy market deregulation during the 2000's, aiming to form a unified supranational energy market satisfying sufficient support to integrate renewable energy sources. In June 2009, the EU directive on the promotion of renewable energy sources (2009/28/EC) entered into effect. It sets binding national targets for all EU member states to reach the European target of $20 \%$ renewable energy sources (RES) share in EU gross final energy consumption by 2020 [25].

\subsection{Open Electricity Markets}

An open electricity market consists of an open competitive wholesale market and a competitive retail market. Often the notion of open electricity market is understood in the narrower sense of meaning only a competitive wholesale market [20]. It consists of a spot market for short-term trading, and a futures exchange as well as individually negotiated OTC ("over the counter") forwards, see Figure 4. The spot market is subdivided into an intraday market for trading electricity for the next hour, often divided in intervals of 5, 15, and 60 minutes, and a day-ahead market for trading electricity for the next day. On the intraday market only quantities are traded which are supplied or demanded due to short-term events.

Nearly all important short-term decisions for power plant generation, however, are made at the day-ahead market. Here electricity for single hours of the next day and at a minimum of $0.1 \mathrm{MW}$ can be traded, for instance a volume of 2 MW for the period from 8 to $11 \mathrm{pm}$.

Besides these hourly contracts there are also traded block contracts ranging over several hours. Block contracts are particularly appropriate for suppliers and demanders with great inertia, i.e., in case of a steady electricity demand or of power plants being not capable to vary the output.

The system price in the spot markets is the market-clearing price and therefore determined by matching offers from generators to bids from consumers at each node to develop a supply and demand equilibrium price, usually on an hourly interval, and is calculated separately for subregions in which the system operator's load flow model indicates that constraints will bind transmission imports. On the day-ahead market, the market-clearing prices are determined by

\begin{tabular}{|c|c|c|}
\hline \multicolumn{2}{|c|}{ spot market } & \multirow{2}{*}{$\begin{array}{c}\text { futures exchange / } \\
\text { OTC forwards }\end{array}$} \\
\hline intraday & day-ahead & \\
\hline \multicolumn{2}{|c|}{ operating reserve } & \\
\hline
\end{tabular}

Figure 4. Time scales of various market segments of European open wholesale electricity markets. Modified from [20]. 
the clearing house once in an hour.

Long-term contracts are traded in normed and standardized form on a future exchange, or as individual forward contracts over the counter between a generator company and a utility or a big consumer. The trading on a future exchange is organized as a continuous open auction.

\section{Locational Marginal Pricing (LMP)}

Locational marginal pricing (LMP), or nodal pricing is an algorithm which first calculates a shadow price at each node on the network, resulting from the optimized redispatch of available units considered as the hypothetical production costs of the additional electricity quantity demanded by the node. The hypothetical redispatch calculation must respect security constraints determined by ancillary services, and must leave sufficient margin to maintain system stability. If the grid consists of a great part of volatile wind turbines and photovoltaic sources, the production costs must regard weather forecasts.

\subsection{Pool-Based Electricity Markets}

A pool-based electricity market is managed and controlled by an independent central pool manager, or market operator. In a pool-based market generating companies and consumer or energy service companies submit bids for selling and buying electric energy for the next 24 hours. The market operator is in charge of clearing the market, determining the accepted and rejected buying and selling bids. The market clearing procedure also provides the market clearing price for every period. Then the market operator decides which power plants are deployed at which time.

Therefore, the price determination in principle is the same as at an open market by calculating a merit order and a demand curve. However, the price includes the costs of grid bottlenecks and of externalities [20].

\subsection{Problems of Electricity Markets}

\subsubsection{The Merit Order Effect}

The merit order is a ranking of available sources of energy in ascending order of their short-run marginal costs of production [20]. Thus those sources with the lowest marginal costs are the first ones to be brought online to meet demand, and the plants with the highest marginal costs are the last to be brought on line. The high demand for electricity during peak demand pushes up the bidding price for electricity, and the relatively inexpensive base load power supply mix is supplemented by "peaking power plants", which charge a premium for their electricity. Increasing the supply of renewable energy tends to lower the average price per unit of electricity because wind energy and solar energy have very low marginal costs: they do not have to pay for fuel, and the sole contributor to their marginal cost is operational cost. As a result, their electricity is less costly than that from coal or natural gas, and transmission companies buy from them first. This wholesale price suppression that occurs when significant volumes of low marginal running cost generation (such as wind or solar PV) are added to a 

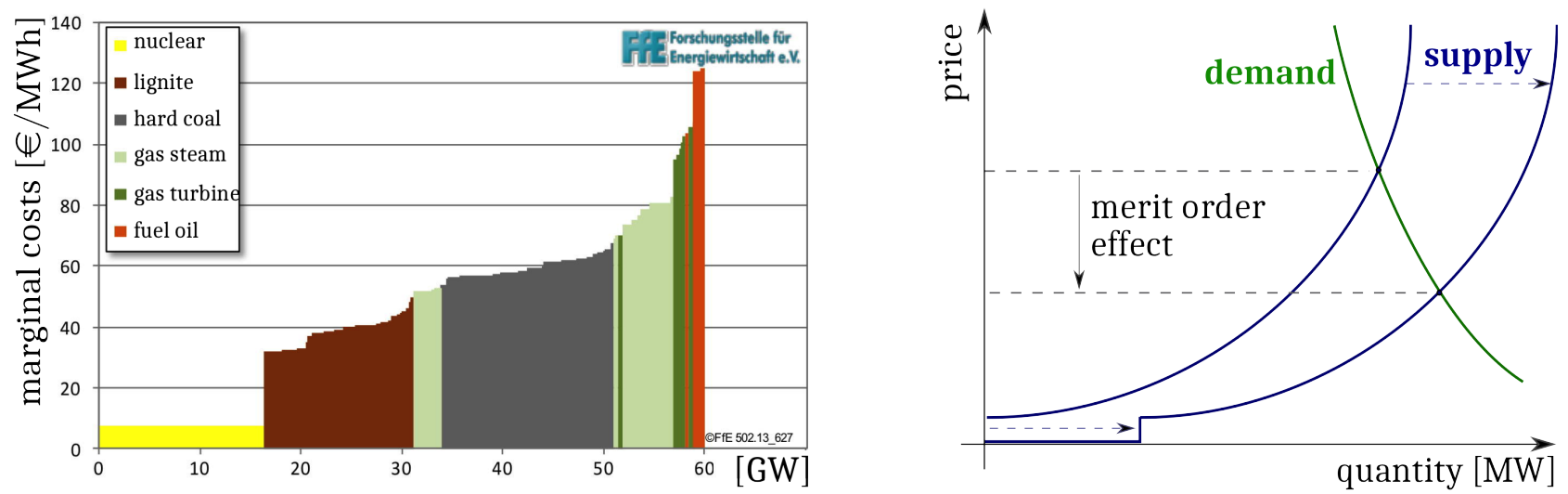

Figure 5. Left: Merit order of residual power plants in Germany 2008 [29]. Right: The merit order effect, caused by a shift of the residual electricity supply curve due to the renewables with low marginal costs.

power system is called the merit order effect [26] [27] [28], cf. Figure 5.

A series of studies covering Germany, Britain, Ontario, Spain, the US and Australia confirms the merit order effect by the observation that, as more renewable resources are added to an existing grid, the more there exists a downward pressure on wholesale prices, see [28] and references therein.

The zero marginal cost of wind energy does not, however, translate, into zero marginal cost of peak load electricity in a competitive open electricity market system as wind supply cannot be dispatched to meet peak demand. The purpose of the merit order was to enable the lowest net cost electricity to be dispatched first thus minimizing overall electricity system costs to consumers. Intermittent wind might be able to supply this economic function provided peak wind supply and peak demand coincide both in time and quantity. On the other hand, solar energy tends to be most abundant during peak energy demand, maximizing its ability to displace coal and natural gas power.

Merit order paradox. The merit order effect leads to the paradox that the more renewably generated energy is fed into the system, the lower gets the wholesale market price of electricity, and thus the less renewables can be refinanced by the spot market [14]. In practice, the merit order effect leads additionally the unwanted effect that modern natural gas turbines are applied only at a rather high market price, i.e., for high demand, although they are ecologically much more advantageous than coal plants.

The merit order paradox is even strengthened by feed-in tariffs [14]. The difference costs emerging by the tariff minus the market price are usually taken by the consumers. This leads to still high consumer prices although the spot market price gets down. The question how renewables can be supported without feed-in tariffs is under debate. Three theoretical models are prominent [30] [31]:

1) Feed-in premium mechanism. Generators sell their renewably produced electricity on the electricity markets and receive a fixed bonus payment, a premium per kWh on top of the electricity price. A feed-in premium scheme is represented by the "market option" in Spain's Real Decreto 661/2007 and formerly Real Decreto 436/2004 [25]. 
2) Quota scheme, based on quota obligations based on tradable green certificates. Generators sell their renewably produced electricity on the electricity markets and the "green value" of their production on special green certificate markets. The demand or green certificates is created by quota obligations for electricity suppliers. A quota scheme is represented by the UK "Renewables Obligation" (RO 2002). One advantage is cost saving since capital intensive technologies like photovoltaics are less implemented, a major disadvantage is a certain suppression of innovations because only mature technologies are supported.

3) Auction mechanism. In a series of competitive orders renewable energy generators submit bids specifying the energy price at which they would be prepared to develop a project and deliver energy. The central agency determines the level of capacity for different technology bands, and the bids that should be accepted and offered contracts to meet this capacity. The bidders are obliged to pay the contracted price. The difference between the contracted price and the market selling price, which represents the subsidy to renewable generation, is reimbursed using funds [29] [32].

\subsubsection{Blackouts as Market Deficiencies}

Electricity markets are not perfect efficient markets. They suffer from the flaw that both the demand and the supply are price inelastic, implying that a market clearing is not warranted: In case of demand excess and exhausted supply capacity a blackout occurs, see Figure 6 . A blackout may be a rolling blackout, during which all available generators produce as much electricity as they can, yet, whatever the price, not all demand can be served [33]. If, however, a blackout leads to a network collapse, it is called catastrophic. A catastrophic blackout thus also leads to a market collapse, because, as electricity cannot be delivered during a system collapse, the consumers are not willing to pay a price anymore. In the sequel therefore the term "blackout" refers to a "rolling blackout" if not specified otherwise.

Blackouts thus occur because of inelasticities of electricity markets. The main reason for the demand-side inelasticity is the lack of real-time meters and billing to allow consumers to respond to real-time prices. The supply side is inelastic because storage of electricity is costly or even impossible. An essential consequence is the following theorem, stating for short that electricity markets cannot optimize blackouts [34].

Theorem 1 (Adequacy Problem). If a competitive electricity market does not

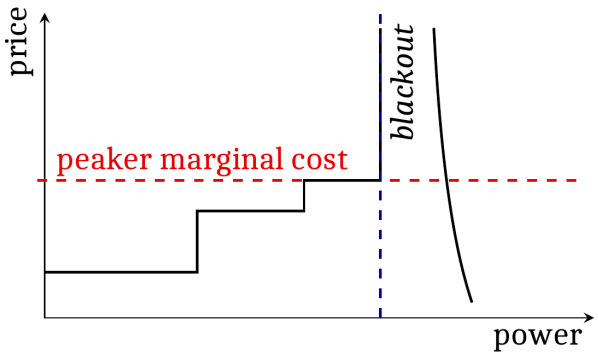

Figure 6. A rolling blackout as a market failure due to inelastic demand and supply. 
prevent the possibility of blackouts, it cannot provide the amount of capacity which optimizes the duration of blackouts.

Proof. [10] By contradiction. Assume that the market provides the amount of capacity optimizing blackout durations. Then it is perfect, i.e., the price always clears the market. In particular, it yields the price being paid during blackouts and thus gives the incentive to build generation capacity to avoid blackouts. However, there does not exist a competitive market price during blackouts since by definition demand does not match supply in this case (Figure 6).

The theorem states the so-called "adequacy problem" saying that a competitive electricity market cannot resolve the trade-off between more capacity and more blackouts in principle. In particular, the price that is being paid to generators during blackouts must be set by administrative rules. The adequacy problem is a crucial challenge in electricity market theory. The duration of blackouts depends on the generation of capacity built to avoid them, and the incentive to build generation capacity to avoid blackouts depends on the price being paid during blackouts. Therefore the determination of the optimal price is critical. If the price is chosen too high, too much capacity is built, but if it is too low, the total duration of blackouts is too long.

Example 2. [10] [35] Define the "value of lost load" VoLL as the amount that consumers would pay per power unit $[\mathrm{MW}]$ to avoid having supply of power interruption during a blackout, see Figure 8, and let RCC be the rental cost of reliable capacity per power unit and year [MW yr]. Then the optimum average duration $w_{\mathrm{bo}}$ of blackouts is given by

$$
w_{\mathrm{bo}}^{*}=\frac{\mathrm{RCC}}{\operatorname{VoLL}}\left[\frac{\mathrm{h}}{\mathrm{yr}}\right] \text {. }
$$

(Note that, if the units are chosen to be equal, then $w_{\mathrm{bo}}^{*}$ is in $[0,1]$, i.e., $w_{\mathrm{bo}}^{*}$ is a probability.) If, for instance, we have VoLL $=\$ 20,000 / \mathrm{MW} \cdot \mathrm{h}$ and RCC $=$ $\$ 80,000 / \mathrm{MW} \cdot \mathrm{yr}$, then the optimum average duration of blackouts is $w_{\mathrm{bo}}^{*}=4$ hours per year. If instead the actual average duration of blackouts is $w_{\mathrm{bo}}=5 \mathrm{~h} / \mathrm{yr}$, then the cost of blackouts is

$$
C_{\mathrm{bo}}=w_{\mathrm{bo}}^{*} \cdot \operatorname{VoLL}=\frac{\$ 100000}{\mathrm{MW} \cdot \mathrm{yr}}>\mathrm{RCC}=w_{\mathrm{bo}}^{*} \cdot \operatorname{VoLL}=\frac{\$ 80000}{\mathrm{MW} \cdot \mathrm{yr}} .
$$

In other words, any MW of capacity added to the system is worth $\$ 100,000$ per year, but the rental cost RCC pays it only $\$ 80,000$ per year. In general, the rental cost RCC of reliable capacity per power unit and year is determined by the expected duration of blackouts wbo and the consumers' value of lost load VoLL through

$$
\mathrm{RCC}=w_{\mathrm{bo}} \cdot \operatorname{VoLL}\left[\frac{\$}{\mathrm{yr}}\right] .
$$

In particular, the rental cost of capacity vanishes if and only if the expected duration of blackout vanishes.

In principle, the only way to resolve the adequacy problem is to remove its logical premise, the market inelasticities. Hence there are two types of solutions 
addressing the adequacy problem. On the one hand, there are approaches to increase supply elasticity by building up and controlling capacity of electricity generation; they are usually subsumed under the category of capacity mechanisms. Another approach is to increase demand elasticity, by enabling real-time price response applying smart metering or smart grids, cf. Figure 7.

However, even though these approaches help to approximate to an efficient market, they do not necessarily solve the closely related problem of the "missing money." The adequacy problem implies insufficient or inefficient incentives to build capacity and to provide reliability in electricity markets, possibly leading to underinvestment in generating capacity. As long as demand is below maximum available capacity, as depicted in Figure 5, suppliers earn the marginal production cost of the peakload technology. However, with effective competition, the peakload resources cannot earn costs that go beyond variable operating and opportunity costs, such as capital investment costs including an appropriate risk adjusted cost of capital.

Theorem 3 (Missing Money Problem). In a competitive electricity market without blackouts, the prices are too low to pay for adequate capacity.

Proof. [9] In competitive markets, capacity only has a positive price when capacity is scarce, as illustrated in Figure 8. Therefore, in normal situations investment costs are sunk and so are not taken into account when bidding into a competitive market.

A crucial implication of this simple observation is that pure-market designs have an inherent tendency to produce scarcity sooner or later:

Corollary 4 (Capacity Dilemma of electricity markets). When generating
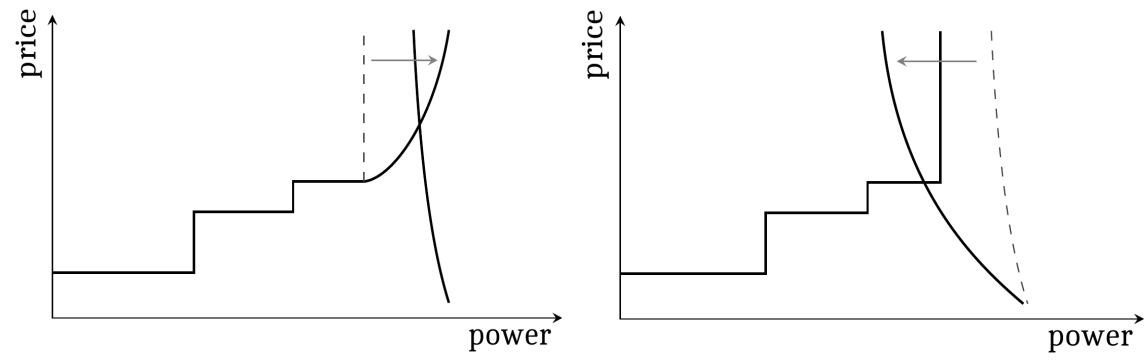

Figure 7. Increasing elasticity on the supply-side by capacity mechanisms (left) and on the demand-side by smart grids (right).
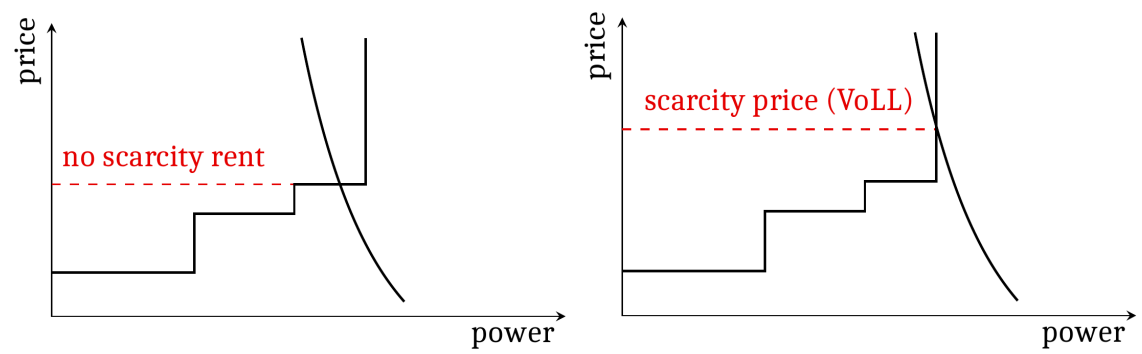

Figure 8. In normal periods with no shortage of capacity there is no scarcity rent (left), in contrast to a scarcity event. In this case, the price of scarcity is also called value of lost load (VoLL). 




Figure 9. Overview of capacity mechanisms and structure of electricity markets.

capacity is adequate in a competitive electricity market, electricity prices are too low to pay for adequate capacity.

\section{Capacity Mechanisms}

Instead of trading solely energy quantities, on a market obeying a capacity mechanism the offering of capacity is paid [26]. The objective is to maintain the grid system reliability. In principle, there are two types of capacity mechanisms, the strategic reserve and capacity markets (Figure 9).

The strategic reserve is a kind of insurance service for short-term emergencies in the electricity system by which electricity quantities are traded on a spot market. The plants warranting the availability of the strategic reserve do not participate at the market. Capacity markets trade capacities, distinguishable whether they are determined by a price mechanism or by a quantity mechanism [10] [17] [36] [37] [38] [39]. In the sequel we will consider only quantity-based capacity markets, since the determination of a price during blackouts is a considerably more difficult task than the determination of required quantity [10].

\subsection{Capacity Markets}

In the mid-1990s, capacity markets were created in the restructured Northeastern US electricity markets in an attempt to provide sufficient remuneration for generators [40]. A capacity-market approach requires that the regulator calculates the level of capacity $C$. that results in the optimal duration of blackouts. The regulator then sets an energy price $P_{\text {cap }}$ during blackouts. This price usually will not necessarily be an efficient price in itself, but it will serve to induce efficient behavior by existing plants and, unlike in an energy-only market, it will have no effect on the level of installed capacity. The global structure of the capacity market models usually discussed is depicted in Figure 10.

In the quantity-based approach to capacity markets, the regulator holds an auction where capacity suppliers bid for a capacity payment $C_{\text {pay }}$. The regulator then determines the optimum capacity $C$ from a target duration of blackouts. Since blackout probabilities depend on the amount of installed capacity, it is possible to back out the value $C$ that is the level of capacity that causes the de- 


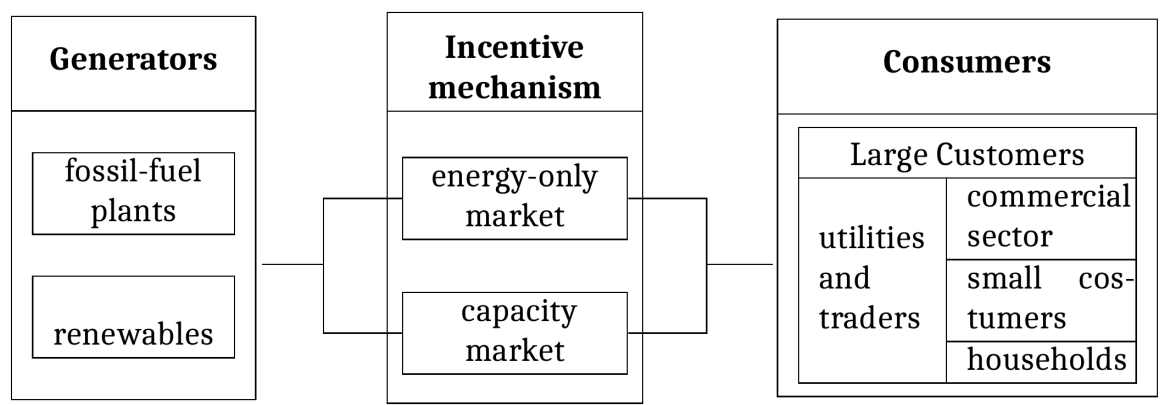

Figure 10. Global structure of short-term energy-only spot market and long-term capacity market.

sired duration of blackouts.

\subsubsection{Central and Decentral Capacity Markets}

A central capacity market complements the energy-only market such that the suppliers can gain revenues from both markets. The clearing price on the capacity markets is determined by multiple-round descending clock auctions. In a central capacity markets there exists a central system operator, or market manager. A decentral capacity market, on the other hand, is characterized by individual demand of reliable capacity. In central capacity markets the product "negative power" is part of a capacity auction, in decentral capacity markets the reduction of demand is a certified product, i.e., reduction of demand reduces the suppliers' obligation to provide capacity [16].

\subsubsection{Supply Contracts and Reliability Options}

By the capacity market design of [9] new entry is coordinated through the forward procurement of reliability options, i.e., physical capacity bundled with a financial option to supply energy at spot prices above a strike price. The market prices capacity from the bids of competitive new entry in a central auction.

Two major advantages of reliability options are that the capacity payment (a) hedges load from high spot prices and (b) reduces supplier risk by replacing peak energy rents, i.e., the rents derived from selling energy at high spot prices during periods of scarcity) with a constant capacity payment. At the same time, spot prices can be as volatile as is required for short-run economic efficiency, as all parties (including load) are exposed to the spot price on the margin. Market power that would emerge in times of scarcity in the spot market is reduced, since suppliers enter the spot market with a nearly balanced position whenever the spot price is above the strike price [10].

\subsubsection{Focussed Capacity Market}

A focussed capacity market is similar to the Cramton-Ockenfels market with reliability options, however there are decentral auctions for various supply segments of the market, e.g., certain categories of power plants.

\subsubsection{Integrated Energy Market Design (iEMD)}

The integrated energy market design (iEMD) is a proposal for a sustainable 


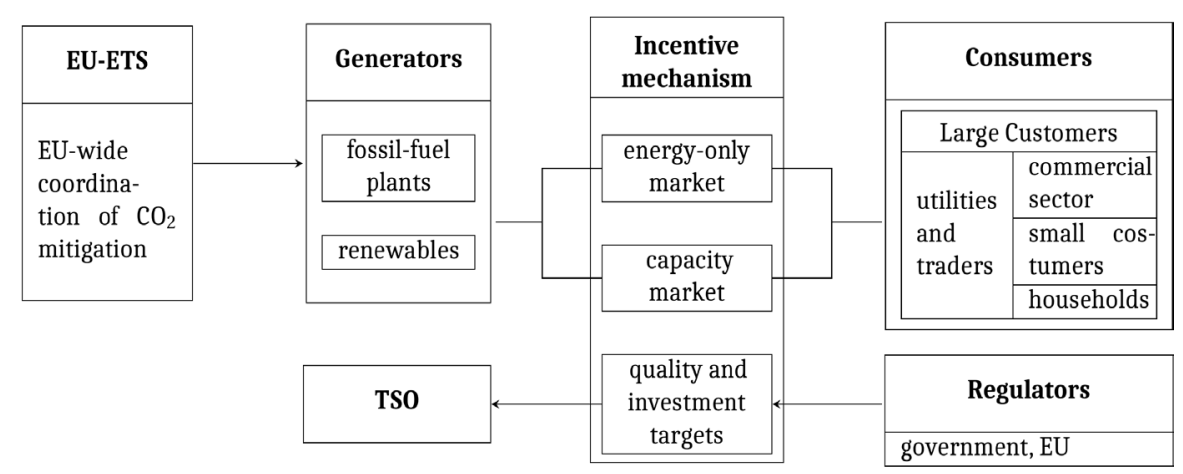

Figure 11. Structure of the integrated market iEMD design of VKU.Modified from [41].

energy market commissioned by the German associations of local utilities, VKU [41]. It separates various markets for each specific core task, enabling the incentive effects to complement one another and to avoid overlapping (Figure 11). In particular, it arranges for a capacity market that operates on the basis of tradable power certificates ("Leistungszertifikate"). Customers secure their demand for reliable capacity by purchasing the power certificates. This feature enables to manage and optimize capacity over the entire value-added chain in an integrated manner.

Consumers with technology that enables demand flexibility will be able to reduce costs for power certificates by reducing their specific contribution to the system's capacity reserves, for instance at peak load times. Demand flexibility will therefore become more attractive in economic terms.

Renewable support scheme. Herrmann and Ecke [42] propose an auctionbased support scheme for renewable energies. On the basis of political long-term targets are defined as quantities of power (MW) that has to be installed, quantity-based paymants in prices of e/MW are sold via round-based auctions (RBA).

\section{Proposal of a New Electricity Market Mechanism}

In this section we introduce a new market mechanism for electricity markets avoiding the market deficiencies mentioned above. It accounts for the operational flexibility of the participating power plants and resolves the missing money problem. It requires the precise definition of a measure of operational flexibility which will be given immediately.

\subsection{A Measure of the Operational Flexibility of a Power Plant}

We stipulate that the operational flexibility of a power plant depends on its guaranteed start-up time $t_{s}$ in $[0, \infty)$ which is defined as the time that a power plant requires to supply a guaranteed power of electricity. Moreover, we claim that the measure should be a pure number expressing a degree of flexibility ranging from 0 to 1 , with the property that the longer the guaranteed start-up time the smaller the value of flexibility. Consequently, we define a general measure of operational flexibility to be a strictly monotonically decreasing function $\varphi:[0, \infty) \rightarrow[0,1]$ of a single variable satisfying the limit behavior 


$$
\varphi(x) \rightarrow 1 \text { as } x \rightarrow 0 \text {, and } \varphi(x) \rightarrow 0 \text { as } x \rightarrow \infty
$$

Here the variable $\mathrm{x}$ represents the starting time of the power plant, measured in hours [h]. A simple example of such a measure is the differentiable function

$$
\varphi(x)=\frac{1}{x+1} .
$$



In the sequel we will use this function to measure the operational flexibility of a given power plant. In Table 2 there are listed guaranteed start-up times $t_{s}$ and the respective flexibility measures $\varphi\left(t_{s}\right)$ for some typical power plants. Note that a wind turbine is assigned a vanishing operational flexibility, since due to the volatility of winds a predetermined amount of energy by a wind turbine cannot be guaranteed at a given future instant. The highest operational flexibilities are exposed by hydroelectric power stations and modern gas turbines.

\subsection{Fees on Operational Inflexibility}

On a wholesale electricity market, each participating power plant operator offers electric power with a sell bid for each of its power plant. The market maker collects all these sell bids and determines the market-clearing price in accordance to the buy bids and the merit order [43] [44] [45] [46], for a theoretical introduction see also [22]. Our main idea now is to rise a fee for operational inflexibility on each power plant, its amount being calculated by the operational flexibility $\varphi$ as part of a factor to a given market-wide reference level. In consequence, the offer price of each power plant must take it into account its operational flexibility.

Table 2. Exemplary cold start-up times and their respective operational flexibility measures, as well as exemplary marginal costs (without emissions trading). The values are typical for current German electricity markets. Data from [45] (start-up times) and [30] [46] (marginal costs).

\begin{tabular}{cccc}
\hline Power Plant & $\begin{array}{c}\text { Guaranteed Cold Start-Up } \\
\text { Time [h] }\end{array}$ & $\phi$ & $\begin{array}{c}\text { Marginal Costs } \\
p^{\mathrm{mc}}[€ / \mathrm{MWh}]\end{array}$ \\
\hline wind turbine & $\infty$ & 0.000 & 1 \\
hydroelectric power station & 0.02 & 0.980 & 1 \\
gas turbine & 0.12 & 0.893 & 50 \\
cogeneration plant (CHP) \\
combined cycle gas turbine \\
hard coal power plant \\
lignite power plant \\
nuclear power plant
\end{tabular}


To be more precise, let $p^{\mathrm{mc}}$ denote the marginal offer price per energy quantity of the power plant regarding only the marginal costs, including the variable costs of production and emissions trade certificates; this is the price which would be offered for the power plant on a current wholesale spot market [30]. Assume moreover that all power plants participating at the spot market are uniquely numbered by the indices $i=1,2, \cdots, n$. The spot market offer price $p_{i}$ of plant $i$ taking into account its operational flexibility $\varphi_{i}$ then is calculated by the formula

$$
p_{i}=p_{i}^{\mathrm{mc}}+\left(1-\varphi_{i}\right) p_{0} .
$$

Here $p_{0}$ denotes a market-wide constant reference level price, set by the market authority. It therefore is a political or regulatory quantity, not a market-inherent value or immediately economically deducible. It is arbitrary in principle, but the higher its amount the heavier the effect of operational flexibility on the final spot market price.

It should be high enough to signal effective incentives to introduce and use operationally flexible power plants for scarcity situations and black-outs, but it must be low enough to avoid a too radical change of the merit order such that too many flexible power plants are operational on the spot market and thus unavailable for a capacity reserve (see Figure 12).

Example 5. Consider a small exemplary grid (called "toy grid" in the sequel) consisting of the eight power plants listed in Table 2. The prices resulting from the respective inflexibility fees in dependence to different reference level prices $p_{0}$ are listed in Table 3. If the reference level price is low (here $p_{0}=10 € / \mathrm{MWh}$ ), the modified offer prices do not change the merit order of the power plant system, whereas a sufficiently high reference level price (e.g., $p_{0}=70 € / \mathrm{MWh}$ ) changes it, as is depicted in Figure 12.

In our toy grid we can recognize that, if the amount of $p_{0}$ is too high, the effect may be even counterproductive since the flexible gas turbine is in the money and thus operating at a normal quantity demand, leaving no power plant as a capacity reserve. In case of a sudden scarcity or of a blackout, the grid then would

Table 3. Operational flexibilities, as given by the exemplary data of Table 2, and the resulting offer price differences with respect to the reference level prices $p_{0}=10 € / \mathrm{MWh}$ and $p_{0}=70 € / \mathrm{MWh}$.

\begin{tabular}{|c|c|c|c|c|c|c|}
\hline \multirow{2}{*}{ Power Plant } & \multirow{2}{*}{ Guaranteed Cold Start-Up Time [h] } & \multirow{2}{*}{$\varphi$} & \multirow{2}{*}{$1-\varphi$} & \multirow{2}{*}{ Marginal Costs $\mathrm{p}_{\mathrm{i}}^{\mathrm{mc}}[€ / \mathrm{MWh}]$} & \multicolumn{2}{|c|}{ Offer Price $p_{\mathrm{i}}[€ / \mathrm{MW}]$} \\
\hline & & & & & $p_{0}=10$ & $p_{0}=70$ \\
\hline Hydroelectric power station & 0.02 & 0.980 & 0.020 & 1 & 1 & 2 \\
\hline Gas turbine & 0.12 & 0.893 & 0.107 & 90 & 91 & 98 \\
\hline Cogeneration plant (CHP) & 0.17 & 0.855 & 0.145 & 50 & 51 & 60 \\
\hline Combined cycle gas turbine & 5 & 0.167 & 0.833 & 50 & 58 & 108 \\
\hline Hard coal power plant & 6 & 0.143 & 0.857 & 60 & 69 & 120 \\
\hline Lignite power plant & 9 & 0.100 & 0.900 & 40 & 49 & 103 \\
\hline
\end{tabular}



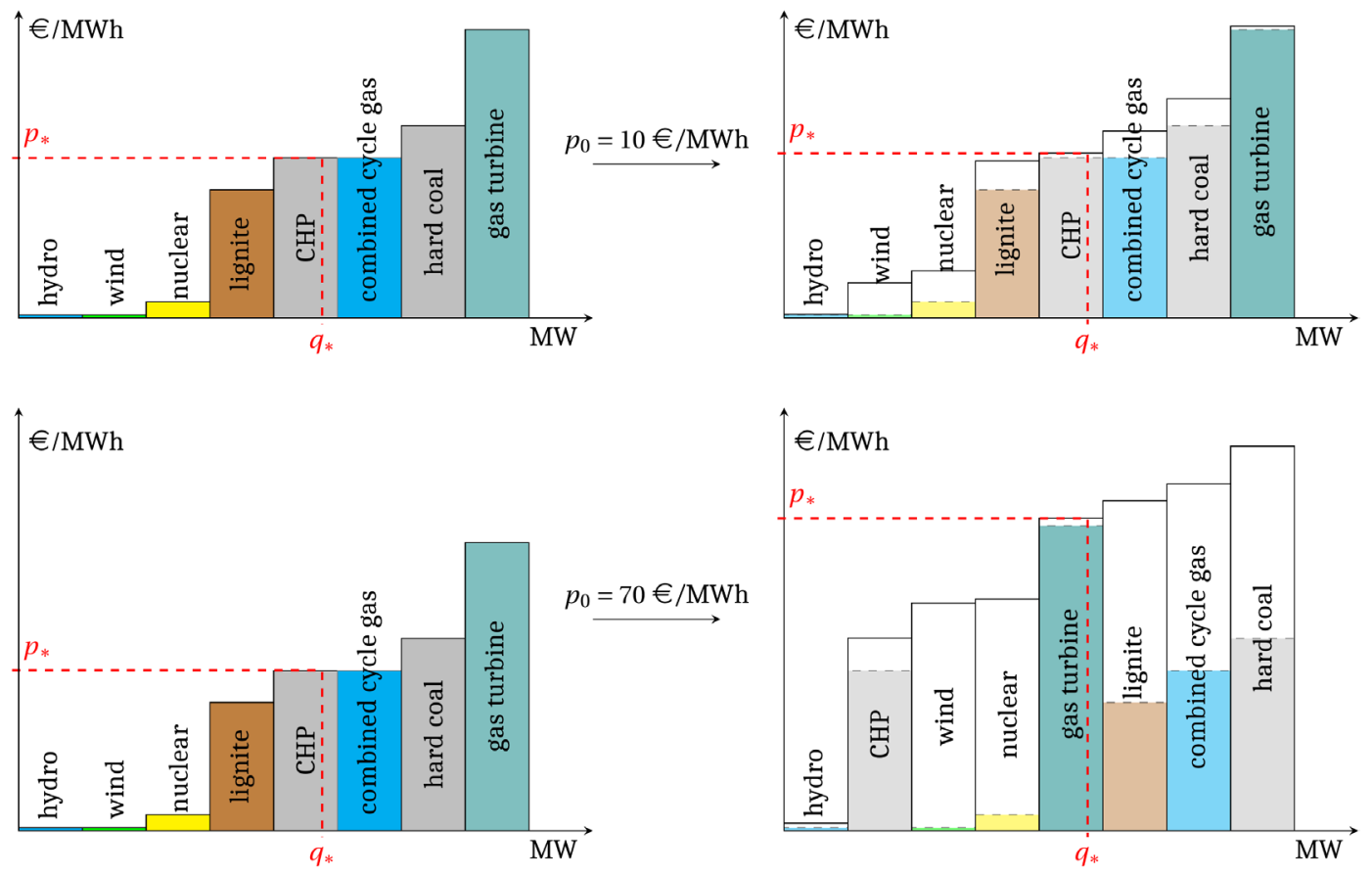

Figure 12. Effect of the operational inflexibility fee on the price $p_{*}$ clearing the market consisting of the power plant system in Table 3, neglecting operational flexibility (left) and regarding it (right). The reference level price are assumed as $p_{0}=10 € / \mathrm{MWh}$ and $p_{0}=70 € / \mathrm{MWh}$, respectively. For a given demand $q_{*}$ of electric power, the market-clearing spot price increases more or less slightly, depending on $p_{0}$. For a high operational inflexibility fee, as in the second case, the merit order is changed.

perform worse than with the original merit order.

Moreover we observe that the higher the reference level price $p_{0}$, the higher the spot market price. The amounts, however, are not related to each other in a linear manner, but depend discontinuously on the changes of the merit order. The total amount of inflexibility fees, at last, is directly calculated to be either $48.4 € / \mathrm{MWh}$ in case of $p_{0}=10 € / \mathrm{MWh}$, or $339 € / \mathrm{MWh}$ in case of $p_{0}=70$ $€ / \mathrm{MWh}$.

We finally note that for the demanded quantity $q_{*}$ depicted in the scenarios in Figure 12, only five power plants are operational.

Assume for simplicity that the demand remains constantly at $q_{*}$ during a certain hour and that all power plants yield the same power of $5 \mathrm{MW}$, say, and let be $q_{*}=25 \mathrm{MW}$ be the demanded electrical power for the hour considered (such that the consumed electricity energy during this period is $E=25 \mathrm{MWh}$ ). Then with Table 3 the total of the inflexibility fees for the five operational power plants in the money has the amount of

$$
C_{f}=(10+0+1+9+10) \times 5=150 € / \mathrm{h},
$$

at a reference level price $p_{0}=10 € / \mathrm{MWh}$, and

$$
C_{f}=(70+1+8+10+69) \times 5=790 € / \mathrm{h},
$$

at a reference level price $p_{0}=70 € / \mathrm{MWh}$. The total fee then can be distributed to the power plants participating at a capacity mechanism, paying their time of reliability. 
The toy grid in Example 5 demonstrates the possible direct consequences of the inflexibility fee to the wholesale electricity market. In essence, by Equation (8) a power plant with a low operational flexibility is penalized more than one with a high operational flexibility. In the limit case that all power plants participating on the spot market are equally operationally flexible, i.e., $\varphi_{i}=$ const, all sell bids are raised by the same amount and the merit order cannot change. On the other hand, if the power plants have different operational flexibilities and the reference price level $p_{0}$ is chosen too high, the merit order changes the merit order such that all flexible power plants are operational on the spot market, such that no power plant is left for the capacity reserve necessary to warrant grid reliability.

The total amount of inflexibility fees paid for each power plants participating the spot market now is available for a capacity mechanism, as described in the following section.

\subsection{Accumulated Inflexibility Fees Paying Capacity Reserves}

A power plant serving as a power reserve for periods of scarcity or blackouts should have fast and guaranteed start-up times, i.e., should be operationally flexible to a high degree. There exist several proposed capacity mechanisms, for instance capacity markets or a strategic reserve determined by a grid agency. In either of these approaches, we therefore require a power plant to offer capacity reserves to have a high operational flexibility $\varphi$, say

$$
\varphi>\frac{1}{2}
$$

This value means that the guaranteed start-up time of a power plant participating the capacity mechanism must be less than one hour. A further natural requirement is that a power plant offering its reliability on the capacity market cannot participate on the spot market.

Assume then that there are $k$ power plants participating on the capacity market, each one established with a unique index $i=1, \cdots, k$. Let $\varphi_{i}$ and $P_{i}$ denote the operational flexibility and the capacity (measured in MW) of power plant $i$, respectively, and let $C_{f}$ be the total of inflexibility fees accumulated on the spot market in a certain past period, say, the day before. It has the dimension currency per time, for instance $€ / \mathrm{h}$. Then the reliability payment $\varphi_{i}$ for power plant $i$ in that period is defined as

$$
\rho_{i}=\frac{\varphi_{i} P_{i}}{P_{\text {flex }}}\left[\frac{€}{h}\right] \text { where } P_{\text {flex }}=\sum_{j=1}^{k} \varphi_{j} P_{j} .
$$

Note that by construction $\rho_{1}+\cdots+\rho_{k}=C_{f}$, i.e., the sum over all reliability payments equals the total amount of the inflexibility fees. The quantity $P_{\text {flex }}$ is the weighted sum of all available capacities, where the weights are precisely the respective operational flexibilities.

Example 6. Assume the toy grid from Example 5. Then by the requirement (11) only three power plants can participate at the capacity market, namely the 
hydroelectric power station, the CHP plant and the gas turbine. In Table 4 they are listed with their capacities and the resulting reliability payments according to Equation (12) and depending on the amount of total inflexibility fee coming from the spot market.

For calculational details refer to the Excel file

http://math-it.org/climate/operational-flexibilities.xls.

\section{Discussion}

In this paper, a proposal has been worked out to integrate operational flexibility into the sell bids of power plants participating wholesale electricity spot markets. The main idea is to calculate a fee for each power plant depending on its operational flexibility. For this purpose, the concept of a general measure of operational flexibility of a power plant is introduced here as a strictly monotonically decreasing function $\varphi$ of the guaranteed start-up time, normed by condition (6). With such a measure, the inflexibility is priced in by Equation (8) to the marginal price determining the sell bid of each power plant at the spot market. The amount depends on a market-wide reference level price $p_{0}$ which is set by the market authority or the state. The total operational inflexibility fee $C_{f}$ is accumulated at the spot markets and then is spread on the power plants participating in a given capacity mechanism, depending on their operational flexibilities according to Equation (12). Here the power plants forming a capacity reserve should have a very high operational flexibility, to guarantee reliability and stability of the grid. A reasonable value is proposed by inequality (11). A simple example of a measure for operational flexibility is given by Equation (7). Using this measure, the spot market and the corresponding payments to power plants participating in a capacity mechanism are applied to a simple but prototypical toy grid in Examples 5 and 6.

The most important consequence of our proposal, as viewed from an economic perspective, is the internalization of the negative externality of operational inflexibility of power plants. With the inflexibility fees determined as above, the currently external costs would thus be paid by the spot markets and could be used to pay capacity reserves, be it on a separate capacity market or another capacity mechanism such as a pool of power plants forming a strategic reserve. The inflexibility fee therefore increases welfare without necessarily decreasing

Table 4. The three power plants participating the capacity market of our toy grid in Example 6 and their reliability payments $\rho_{i}$ in dependence to the total inflexibility fee coming from the spot market.

\begin{tabular}{cccccccc}
\hline \multirow{2}{*}{ Power Plant } & $\boldsymbol{\varphi}$ & Capacity [MW] & \multicolumn{4}{c}{$\rho_{\boldsymbol{i}}[€ / \mathrm{h}]$} \\
\cline { 5 - 7 } & & & \multicolumn{2}{c}{$C_{f}=205 € / \mathrm{h}$} & $C_{f}=790 € / \mathrm{h}$ \\
\hline Hydroelectric power station & 0.980 & 5 & 74 & - & 284 \\
Gas turbine & 0.893 & 5 & 67 & 105 & 259 & 404 \\
Cogeneration plant (CHP) & 0.855 & 5 & 64 & 100 & 248 & 386 \\
\hline
\end{tabular}


dispatch efficiency.

A critical point of our approach, however, is the determination of the reference level price $p_{0}$. It is crucial since it can even change the merit order of electricity markets if it is set very high. Although a change of the merit order in itself does not necessarily imply severe problems, it could nonetheless lead to the paradox that operationally flexible power plants participate in a short-term spot market and therefore could not serve as a capacity reserve. An amount $p_{0}$ too high would thus be adverse to the intention to pay a capacity mechanism and thus would even diminish welfare. We therefore are faced with the conflicting objectives of providing enough means to fund the reserves of a capacity mechanism, and of keeping suitable power plants with high operational flexibility as capacity reserve. Although this risk is calculable when choosing the amount for a given grid cautiously such that experiences could be gained over time, a comprehensive theoretical framework to illuminate effects and limits of inflexibility fees on electricity markets should be accomplished. Hints to tackle this problem may be indicated by the optimal taxation due to Ramsey [47], or by regulation theory [20]. Further research in this direction appears worthwhile. The alternatives are not comfortable: Without an appropriate market mechanism, we either obtain an electricity market which externalizes the costs of capacity reserves and is unstable, or a market which cannot include market principles to rule the determination of stability costs.

\section{References}

[1] Foster, J.B., Clark, B. and York, R. (2010) The Ecological Rift. Capitalism's War on the Earth. Monthly Review Press, New York.

[2] IPCC (2007) Climate Change 2007. The Physical Science Basis. Contribution of Working Group I to the Fourth Assessment Report of the IPCC. Cambridge University Press, Cambridge, New York. http://www.ipcc.ch/pdf/assessment-report/ar4/wg1/ar4_wg1_full_report.pdf

[3] IPCC (November 2013) Climate Change 2013: The Physical Science Basis. Contribution of Working Group I to the Fifth Assessment Report of the IPCC. Cambridge University Press, Cambridge, New York. http://www.climatechange2013.org

[4] IPCC (March 2014) Climate Change 2014: Impacts, Adaptation, and Vulnerability. Contribution of Working Group II to the Fifth Assessment Report of the IPCC. Cambridge University Press, Cambridge, New York. http://ipcc.ch/report/ar5/wg2/

[5] Rockström, J., Steffen, W., Noone, K., Persson, Å., Chapin, F.S., Lambin, E., Lenton, T.M., Scheffer, M., Folke, C., Schellnhuber, H.J., Nykvist, B., de Wit, C.A., Hughes, T., van der Leeuw, S., Rodhe, H., Sörlin, S., Snyder, P.K., Costanza, R., Svedin, U., Falkenmark, M., Karlberg, L., Corell, R.W., Fabry, V.J., Hansen, J., Walker, B., Liverman, D., Richardson, K., Crutzen, P. and Foley, J. (2009) Planetary Boundaries: Exploring the Safe Operating Space for Humanity. Ecology and Society, 14, 32. http://www.ecologyandsociety.org/vol14/iss2/art32/ https://doi.org/10.5751/ES-03180-140232

[6] Rockström, J., Steffen, W., Noone, K., Persson, Å., Chapin, F.S., Lambin, E.F., Lenton, T.M., Scheffer, M., Folke, C., Schellnhuber, H.J., Nykvist, B., de Wit, C.A., Hughes, T., van der Leeuw, S., Rodhe, H., Sörlin, S., Snyder, P.K., Costanza, R., Svedin, U., Falkenmark, M., Karlberg, L., Corell, R.W., Fabry, V.J., Hansen, J., Walker, 
B., Liverman, D., Richardson, K., Crutzen, P. and Foley, J.A. (2009) A Safe Operating Space for Humanity. Nature, 461, 472-475. https://doi.org/10.1038/461472a

[7] Edenhofer, O., Madruga, R.P., Sokona, Y., Seyboth, K., Matschoss, P., Kadner, S., Zwickel, T., Eickemeier, P., Hansen, G., Schlšmer, S. and von Stechow, C., Eds. (2012) Renewable Energy Sources and Climate Change Mitigation. Special Report of the Intergovernmental Panel on Climate Change. Cambridge University Press, Cambridge. http://www.ipcc.ch/pdf/special-reports/srren/SRREN_Full_Report.pdf

[8] Agora Energiewende (2013) 12 Insights on Germany's Energiewende. A Discussion Paper Exploring Key Challenges for the Power Sector.

https://www.agora-energiewende.de/en/topics/-agothem-/Produkt/produkt/86

[9] Cramton, P. and Ockenfels, A. (2012) Economics and Design of Capacity Markets for the Power Sector. Zeitschrift für Energiewirtschaft, 36, 113-134. https://doi.org/10.1007/s12398-012-0084-2

[10] Cramton, P., Ockenfels, A. and Stoft, S. (September 2013) Capacity Market Fundamentals.

http://www.cramton.umd.edu/papers2010-2014/cramton-ockenfels-stoft-capacitymarket-fundamentals.pdf

[11] Agora Energiewende (2013) Capacity Market or Strategic Reserve: What's the Next Step?

http://www.agora-energiewende.org/topics/electricity-market-and-system-reliability/

[12] Ecke, J., Herrmann, N., Hilmes, U., Kremp, R., Macharey, U., Nolde, A., Wolter, H. and Zander W. (June 2013) A Sustainable Energy Market Design for Germany (Condensed Version). VKU, Berlin.

http://www.vku.de/energie/energiemarktdesign.html

[13] Elberg, C., Growitsch, C., Höffler, F. and Richter, J. (2012) Untersuchungen zu einem zukunftsfŠhigen Strommarktde.sign. Cologne, März 2012. Endberichtim Auftrag des BMWi.

http://www.ewi.research-scenarios.de/de/research-scenarios/studien-projekte/\#tabwirtschaft-2012

[14] Steuwer, S.D. (2013) Instrumente der Energiewende. In: Varwick, J., Ed., Energiewende, Politische Bildung. Beiträge zur wissenschaftlichen Grundlegung und zur Unterrichtspraxis, Wochenschau Verlag, Schwalbach, 46-70.

[15] Gawel, E. and Purkus, A. (2013) Die Marktprämie im EEG 2012: Ein sinnvoller Beitrag zur Markt-und Systemintegra.tion erneuerbarer Energien? Zeitschrift für Energiewirtschaft, 37, 43-61. https://doi.org/10.1007/s12398-012-0097-x

[16] Growitsch, C., Matthes, F.C. and Ziesing, H.-J. (March 2013) Clearing-Studie KapazitŠtsmŠrkte. Berlin Cologne, im Auftrag des BMWi.

http://www.ewi.research-scenarios.de/de/research-scenarios/studien-projekte/\#tabwirtschaft-2013

[17] Matthes, F.C., Schlemmermeier, B., Diermann, C., Hermann, H. and von Hammerstein, C. (2012) Fokussierte Kapazitätsmärkte. Ein neues Marktdesign für den Übergang zu einem neuen Energiesystem. WWF Deutschland, Berlin.

http://www.wwf.de/fileadmin/fm-wwf/Publikationen-PDF/Fokussierte-Kapazitaets maerkte.pdf

[18] Bofinger, P. (2007) Grundzüge der Volkswirtschaftslehre. Eine Einführung in die Wissenschaft von Märkten. 2nd Edition, Pearson Studium, München.

[19] Krugman, P. and Wells, R. (2006) Macroeconomics. Worth Publishers, New York.

[20] Ströbele, W., Pfaffenberger, W. and Heuterkes, M. (2012) Energiewirtschaft. Einfüh-rung in Theorie und Politik. 3rd Edition, Oldenbourg, München.

[21] Agora Energiewende (2015) The Role of Emissions Trading in the Energy Transi- 
tion.

https://www.agora-energiewende.de/en/topics/-agothem-/Produkt/produkt/186/

[22] Fudenberg, D. and Tirole, J. (1991) Game Theory. MIT Press, Cambridge.

[23] Holler, M.J. and Illing, G. (1996) Einführung in die Spieltheorie. 3rd Edition, Springer-Verlag, Berlin, Heidelberg, New York.

[24] Jamasb, T. and Pollitt, M. (2005) Electricity Market Reform in the European Union: Review of Progress toward Liberalization \& Integration. The Energy Journal, 26, 1141. https://doi.org/10.5547/ISSN0195-6574-EJ-Vol26-NoSI-2

[25] Klessmann, C., Nabe, C. and Burges, K. (2008) Pros and Cons of Exposing Renewables to Electricity Market Risks-A Comparison of the Market Integration Approaches in Germany, Spain, and the UK. Energy Policy, 36, 3646-3661.

[26] Sensfuß, F., Ragwitz, M. and Genoese, M. (2008) The Merit-Order Effect: A Detailed Analysis of the Price Effect of Renewable Electricity Generation on Spot Market Prices in Germany. Energy Policy, 36, 3086-3094.

http://hdl.handle.net/10419/28511

[27] O'Mahoney, A. and Denny, E. (2011) The Merit Order Effect of Wind Generation in the Irish Electricity Market. 30th IAEE/USAEE North American Conference, Washington DC.

[28] Nelson, T., Simshauser, P. and Nelson, J. (2012) Queensland Solar Feed-In Tariffs and the Merit-Order Effect: Economic Benefit, or Regressive Taxation and Wealth Transfers? Economic Analysis \& Policy, 42, 277-301.

[29] von Roon, S. and Huck, M. (2010) Merit Order des Kraftwerkparks. Forschungsstelle für Energiewirtschaft, München. http://www.ffe.de/download/wissen/20100607_Merit_Order.pdf

[30] Butler, L. and Neuhoff, K. (2008) Comparison of Feed-In Tariff, Quota and Auction Mechanisms to Support Wind Power Development. Renewable Energy, 33, 18541867.

[31] Jacobs, D. (2012) Renewable Energy Policy Convergence in the EU. The Evolution of Feed-In Tariffs in Germany, Spain and France. Ashgate Publishing, Surrey. http://books.google.de/books?id=iRm4mz_gmVsC

[32] Bataille, M. and Hösel, U. (2014) Energiemarkteffzienz und das Quotenmodell der Monopolkommission. DICE Ordnungspolitische Perspektiven 57, Düsseldorf Institute for Competition Economics (DICE), Düsseldorf. http://hdl.handle.net/10419/92557

[33] Stoft, S. (2002) Power System Economics. Designing Markets for Electricity. IEEE Press Wiley, Piscataway, NJ.

[34] Joskow, P.L. (2006) Competitive Electricity Markets and Investment in New Generating Capacity. AEI-Brookings Joint Center Working Paper, No. 06-14.

[35] Stoft, S. (2003) The Demand for Operating Reserves: Key to Price Spikes and Investment. IEEE Transactions on Power Systems, 18, 470-477. https://doi.org/10.1109/TPWRS.2003.810679

[36] Cramton, P. and Ockenfels, A. (2011) Ökonomik und Design von Kapazitätsmärkten im Stromsektor. Energiewirtschaftliche Tagesfragen, 61, 14-15. http://www.cramton.umd.edu/papers2010-2014/cramton-ockenfels-economics-and -design-of-capacity-markets.pdf

[37] Ecke, J., Herrmann, N., Hilmes, U., Kremp, R., Macharey, U., Nolde, A., Wolter, H. and Zander, W. (March 2013) Ein zukunftsfähiges Energiemarktdesign für Deutschland. VKU, Berlin. http://vku.de/energie/energiemarktdesign.html

[38] Herrmann, N. and Ecke, J. (2013) Auktionierung von Kapazitätsprämien für 
erneuerbare Energien-Vorschlag für eine Neugestaltung des Fördermechanismus. Vierteljahrshefte zur Wirtschaftsforschung, 82, 137-153. https://doi.org/10.3790/vjh.82.3.137

[39] Nicolosi, M. (2012) Notwendigkeit und Ausgestaltungsmöglichkeiten eines Kapazitätsmechanismus für Deutschland. Umweltbundesamt, Dessau. http://www.uba.de/uba-info-medien/4221.html

[40] Bidwell, M. (2005) Reliability Options: A Market-Oriented Approach to Long-Term Adequacy. The Electricity Journal, 18, 11-25.

[41] Das, R., Hanson, J.E., Kephart, J.O. and Tesauro, G. (2001) Agent-Human Interactions in the Continuous Double Auction. Proceedings of the 17 th International Joint Conference on Artificial Intelligence, 2, 1169-1176. http://citeseer.ist.psu.edu/viewdoc/summary?doi=10.1.1.72.177

[42] EPEX (2014) EPEX Spot in the Power Market. Paris Leipzig Wien. http://www.epexspot.com/en/company-info/epex_spot_in_the_power_market

[43] Wilson, R. (1985) Incentive Efficiency of Double Auctions. Econometrica, 53, 11011115. http://www.jstor.org/stable/1911013 https://doi.org/10.2307/1911013

[44] Satterthwaite, M.A. and Williams, S.R. (1989) Bilateral Trade with the Sealed Bid k-Double Auction: Existence and Efficiency. Journal of Economic Theory, 48, 107133.

[45] Grimm, V. (2007) Einbindung von Speichern für erneuerbare Energien in die Kraftwerkseinsatzplanung-Einfluss auf die Strompreise der Spitzenlast. PhD Thesis, Ruhr University Bochum, Bochum.

http://www-brs.ub.ruhr-uni-bochum.de/netahtml/HSS/Diss/GrimmVanessa/diss.p df

[46] Heitmann, N. (2010) Modellierung von Investitionsentscheidungen und Kraftwerkseinsatzplanung unter Unsicherheit mittels Stochastischer Optimierung und MultiAgenten-Ansatz am Beispiel des deutschen Strommarktes. PhD Thesis, University of Augsburg, Augsburg.

http://opus.bibliothek.uni-augsburg.de/opus4/frontdoor/deliver/index/docId/2094/f ile/Dissertation_Heitmann.pdf

[47] Ramsey, F.P. (1927) A Contribution to the Theory of Taxation. The Economic Journal, 37, 47-61. http://www.jstor.org/stable/2222721

https://doi.org/10.2307/2222721 
Submit or recommend next manuscript to SCIRP and we will provide best service for you:

Accepting pre-submission inquiries through Email, Facebook, LinkedIn, Twitter, etc. A wide selection of journals (inclusive of 9 subjects, more than 200 journals)

Providing 24-hour high-quality service

User-friendly online submission system

Fair and swift peer-review system

Efficient typesetting and proofreading procedure

Display of the result of downloads and visits, as well as the number of cited articles Maximum dissemination of your research work

Submit your manuscript at: http://papersubmission.scirp.org/

Or contact me@scirp.org 